\title{
ESTIMASI INDIKATOR KEMISKINAN TINGKAT KECAMATAN MENGGUNAKAN REGRESI KEKAR M-KUANTIL
}

\begin{tabular}{|c|}
\hline Nia Aprillyana \\
Badan Pusat Statistik \\
nia_aprillyana@bps.go.id
\end{tabular}

Diterima: Maret 2019; Direvisi: April 2019; Disetujui: Mei 2019

\begin{abstract}
The poverty indicators is one of the strategic figures in Indonesia to determine country development policies. The poverty indicators is divided into three, namely the Headcount Ratio (HCR), Poverty Gap (PG), and Poverty Severity (PS). Through the National Socio-Economic Survey (Susenas), Statistics Indonesia (BPS) is only able to estimate poverty indicators until the district level. On the other hand, sub-district poverty indicators are needed by regional governments to determine the regional policies. Some branch of BPS conduct an additional survey (namely Suseda) to increase the number of samples so they could estimate until the sub-district level. However, the increasing of the number of samples could not be conduct by all branch of BPS because of the constrained costs. To solve the problem, we need a model-based small area estimation technique which only uses original samples of Susenas. The small area estimation technique used the Mquantile regression model which robust to the outliers. This model used the influence function and the quantile value in weighting the residual to produce an estimate of the regression coefficient. In the last part, this study calculated the comparison of accuracy between the increasing of the number of samples and the use of models in producing poverty indicators at the sub-district level. To evaluate accuracy, we use RRMSE for each sub-district poverty indicators estimation.
\end{abstract}

Keywords: influence function, m-quantile, poverty indicator, small area estimation.

Abstraksi. Indikator kemiskinan merupakan salah satu angka strategis di Indonesia untuk menentukan kebijakan pembangunan. Indikator kemiskinan terbagi menjadi tiga yaitu Angka Kemiskinan $\left(P_{0}\right)$, Kedalaman Kemiskinan $\left(P_{1}\right)$, dan Keparahan Kemiskinan $\left(P_{2}\right)$. Badan Pusat Statistik (BPS) melalui sampel Survei Sosial Ekonomi Nasional (Susenas) hanya mampu mengestimasi angka indikator kemiskinan sampai tingkat kabupaten. Disisi lain, angka kemiskinan tingkat kecamatan sangat dibutuhkan pemerintah daerah untuk menentukan kebijakan daerah. BPS kabupaten beberapa mengadakan survei tambahan (Suseda) untuk menambah sampel sehingga bisa mengestimasi sampai tingkat kecamatan. Akan tetapi, penambahan sampel terkadang tidak bisa dilakukan semua kabupaten karena terkendala biaya. Untuk menangani masalah tersebut, dibutuhkan teknik estimasi area kecil berbasis model yang hanya menggunakan sampel yang ada di Susenas saja tanpa penambahan sampel untuk memperoleh angka indikator kemiskinan tingkat kecamatan. Penelitian ini ingin mengetahui perbandingan akurasi antara adanya penambahan sampel dengan pemakaian model dalam menghasilkan angka indikator kemiskinan tingkat kecamatan. Teknik estimasi area kecil yang digunakan adalah model regresi M-kuantil yang kekar terhadap outlier. Model ini memakai fungsi pengaruh dan nilai kuantil dalam memboboti residual untuk menghasilkan estimasi koefisien regresi. Untuk mengevaluasi akurasi, digunakan RRMSE untuk setiap estimasi indikator kemiskinan tingkat kecamatan.

Kata kunci: fungsi pengaruh, m-kuantil, indikator kemiskinan, estimasi area kecil. 


\section{PENDAHULUAN}

Survei nasional memiliki peran penting dalam menghasilkan indikator strategis untuk mendukung pembangunan suatu negara. Tujuan utama dari survei nasional adalah untuk menduga parameter sebuah populasi. Survei nasional hanya menyediakan informasi terbatas dan hanya menduga populasi atau sub populasi besar sebagaimana dinyatakan Molina dan Rao (2010). Survei nasional memiliki varian yang besar dan akurasi yang rendah ketika mengestimasi level area yang lebih kecil (seperti kecamatan atau desa) karena ketidakcukupan sampel.

Untuk meningkatkan akurasi, pelaksana survei akan menambah jumlah sampel atau yang disebut dengan oversampling. Oversampling memiliki dua manfaat yaitu untuk menyediakan pendugaan yang akurat dan untuk menangani non-respon (Kennickell 2007). Akan tetapi oversampling tidak efisien karena membutuhkan biaya yang lebih besar, sehingga dibutuhkan alternatif teknik estimasi lain dengan hanya menggunakan sampel kecil (Giusti, Marchetti, Pratesi, \& Salvati 2012) yang disebut dengan estimasi tidak langsung atau estimasi yang berbasis pada model. Rao menyatakan bahwa estimasi tidak langsung dapat diimplementasikan dengan "meminjam informasi" atau memanfaatkan variabelvariabel tambahan (variabel penyerta) yang didapatkan pada area lain dari survei yang sama, dari area yang sama pada survei terdahulu, atau variabel lain yang berhubungan dengan variabel yang menjadi perhatian pada area kecil (Rao 2003).

Salah satu indikator pembangunan strategis yang angkanya hanya tersedia untuk level nasional, provinsi, dan kabupaten/kota adalah indikator kemiskinan. Di Indonesia, indikator kemiskinan secara resmi dihitung oleh BPS melalui Survei Sosial Ekonomi Nasional (Susenas) untuk estimasi tingkat kabupaten, provinsi, dan nasional (BPS, 2016).

Pemerintah daerah sebagai pelaksana kebijakan tingkat daerah tentu membutuhkan indikator kemiskinan hingga level area kecil (kecamatan dan desa). Indikator kemiskinan area kecil biasa diperoleh dengan penambahan sampel di luar survei utama Susenas, atau disebut dengan Survei Sosial Ekonomi Daerah (Suseda). Salah satu kabupaten yang melaksanakan Suseda sekaligus menjadi objek/wilayah penelitian ini adalah Kabupaten Musi Rawas, Provinsi Sumatera Selatan. Di awal pendahuluan telah dijelaskan bahwa penambahan sampel sulit dilakukan karena sejumlah batasan (biaya dan waktu), sehingga penelitian ini mencari alternatif dalam penghitungan indikator kemiskinan yang berbasis pada model.

Penelitian ini fokus pada model Mkuantil karena karakteristik data pengeluaran perkapita rumah tangga pada objek penelitian terbukti heavy tailed atau menceng ke kanan. M-kuantil adalah suatu metode semiparametrik yang berbasis kuantil yang menjamin estimasi yang bersifat kekar dan tidak memerlukan asumsi sebaran teoritis sebagaimana dinyatakan oleh Chambers dan Tzavidis (2006). Mkuantil tidak bergantung pada asumsi distribusi yang kuat dan secara otomatis menyediakan kesimpulan yang kekar terhadap pencilan (Chambers \& Tzavidis, 2006; Tzavidis, Marchetti \& Chambers, 2010; Marchetti, Tzavidis \& Pratesi, 2012). M-kuantil menggunakan M-estimator yang memberikan bobot kecil terhadap pencilan (dan residual) dan mengabaikan asumsi yang harus ada pada Metode Kuadrat Terkecil (MKT). Beberapa M-estimator yang bisa dimanfaatkan dalam model M- 
kuantil yaitu Huber dan Hampel. Beberapa studi mengenai M-kuantil lebih sering menggunakan fungsi pengaruh Huber dibandingkan dengan fungsi lainnya sebagaimana yang dilakukan oleh Giusti, Marchetti, Pratesi \& Salvati (2012) dan Girinoto (2017).

Di akhir analisis, penelitian ini mengevaluasi akurasi estimasi indikator kemiskinan yang dihasilkan M-kuantil dengan akurasi estimasi indikator kemiskinan yang dihasilkan estimasi langsung pada sampel yang telah ditambahkan (Suseda). Apabila hasilnya sama atau lebih akurat, maka teknik Mkuantil bisa menjadi alternatif dalam estimasi kemiskinan di area kecil. Selain itu, penelitian juga membandingkan dua fungsi pengaruh (Huber dan Hampel) dalam proses pembentukan model. Fungsi mana yang lebih menjamin untuk menghasilkan model yang paling akurat.

\section{METODE PENELITIAN}

\section{Landasan Teori}

Kemiskinan dipandang sebagai ketidakmampuan dari sisi ekonomi untuk memenuhi kebutuhan dasar makanan dan bukan makanan yang diukur dari sisi pengeluaran (BPS 2016). Garis Kemiskinan (GK) merupakan penjumlahan dari Garis Kemiskinan Makanan (GKM) dan Garis Kemiskinan Non Makanan (GKNM). GKM merupakan nilai pengeluaran kebutuhan minimum makanan yang disetarakan dengan 2100 kilo kalori perkapita perhari. Paket komoditi kebutuhan dasar makanan diwakili oleh 52 jenis komoditi (padipadian, umbi-umbian, ikan, daging, telur dan susu, sayuran, kacang-kacangan, buahbuahan, minyak dan lemak, dll). GKNM adalah kebutuhan minimum untuk perumahan, sandang, pendidikan, dan kesehatan.
Berdasarkan pendekatan kebutuhan dasar, BPS menggunakan tiga indikator kemiskinan, yaitu :

Head Count Ratio (HCR- $\left.\mathrm{P}_{0}\right)$, yang disebut sebagai persentase penduduk miskin, merupakan persentase penduduk yang berada di bawah garis kemiskinan (GK).

Poverty Gap Index ( $\left.\mathrm{PG}-\mathrm{P}_{1}\right)$, yang disebut sebagai indeks kedalaman kemiskinan yang merupakan ukuran ratarata kesenjangan pengeluaran masingmasing penduduk miskin terhadap garis kemiskinan. Semakin tinggi nilai indeks, semakin jauh rata-rata pengeluaran penduduk dari garis kemiskinan.

Poverty Severity Index (PS- $\left.\mathrm{P}_{2}\right)$, yang disebut sebagai indeks keparahan kemiskinan yang memberikan gambaran mengenai penyebaran pengeluaran di antara penduduk miskin. Semakin tinggi nilai indeks, semakin tinggi ketimpangan pengeluaran di antara penduduk miskin.

Foster et al. (1984) merumuskan suatu ukuran untuk mengukur tingkat kemiskinan untuk area kecil d. Rumus berikut disesuaikan dengan konteks penelitian:

$$
F_{\alpha, d}=\frac{1}{N_{d}} \sum_{j=1}^{N_{d}}\left(\frac{t-y_{j d}}{t}\right)^{\alpha} I\left(\boldsymbol{y}_{j d} \leq t\right)(1)
$$

Di mana :

$d \quad=$ kecamatan $(d=1,2, \ldots, \mathrm{D})$

$\alpha=$ koefisien sensitivitas (0 untuk $P_{0}$,

1 untuk $P_{1}, 2$ untuk $P_{2}$ )

$\mathbf{y}_{j d} \quad=$ pengeluaran per kapita unit $j \mathrm{di}$ area $d$

$t \quad=$ Garis Kemiskinan $(\mathrm{GK})$

$N_{d} \quad=$ Banyaknya populasi rumah tangga di kecamatan $d$

$I\left(\mathbf{y}_{j d} \leq t\right)$ fungsi indikator suatu unit rumah tangga dibawah GK.

$I\left(\mathbf{y}_{j d} \leq t\right)=1$ jika $\mathbf{y}_{j d} \leq t$ dan $I\left(\mathbf{y}_{j d} \leq\right.$ $t)=0$ jika $\mathbf{y}_{j d}>t$. 
Di tahap awal penelitian, kami menghitung indikator kemiskinan dengan metode estimasi langsung. Estimasi dikatakan langsung apabila estimasi terhadap parameter populasi di suatu area hanya didasarkan pada data sampel yang diperoleh dari area tersebut. Pada metode estimasi langsung, penghitungan estimasi $P_{0}$ dan $P_{1}$ tiap kecamatan-d hanya menggunakan $\mathbf{y}_{j d}$ dari gugus sampel. Gugus sampel dalam penghitungan estimasi langsung merupakan penggabungan sampel Susenas dan Suseda (oversampling).

Estimasi langsung pada penghitungan indikator kemiskinan merujuk pada rumus umum FGT, menjadi:

$$
\hat{P}_{\alpha, d}^{D i r}=\frac{1}{n_{d}} \sum_{j=1}^{n_{d}}\left(\frac{t-\boldsymbol{y}_{j d}}{t}\right)^{\alpha} I\left(\boldsymbol{y}_{j d} \leq t\right)(2)
$$

Di mana:

$d=$ kecamatan di Kabupaten Musi Rawas $(d=1,2, \ldots . .14)$

$\alpha=$ koefisien sensitivitas $\left(0\right.$ untuk $P_{0}, 1$ untuk $P_{1}$ )

$\mathbf{y}_{j d}=$ pengeluaran perkapita rumah tangga $j$ di kecamatan $d$

$t=$ Garis Kemiskinan (GK) di kecamatan $d$

$n_{d}=$ Banyaknya sampel rumah tangga di kecamatan $d$

$I\left(\mathbf{y}_{j d} \leq t\right)$ fungsi indikator suatu unit dibawah GK di kecamatan $d$

Setelah melakukan estimasi langsung, penghitungan selanjutnya menggunakan model M-kuantil. M-kuantil menggunakan data Susenas 2015 sebagai penyedia variabel respon dalam pemodelan. Selain itu, penghitungan estimasi indikator kemiskinan $P_{0}, P_{1}$, dan RRMSE melalui M-kuantil membutuhkan variabel penyerta yang diperoleh dari data Sensus Penduduk 2010 (SP2010) di level rumah tangga. Variabel penyerta dipilih berdasarkan hubungan dengan variabel respon dan disesuaikan dengan ketersediaan data populasi SP2010.

Model M-kuantil diperoleh dengan mendekomposisi persamaan:

$$
\hat{P}_{\alpha, d}=N_{d}^{-1}\left(\sum_{j \epsilon s_{d}} \hat{P}_{\alpha, j d}+\sum_{j \epsilon r_{d}} \hat{P}_{\alpha, k d}\right)(3)
$$

Di mana:

$\widehat{P}_{\alpha, j d}$ adalah estimasi indikator kemiskinan untuk gugus sampel

$\hat{P}_{\alpha, k d}$ adalah estimasi indikator kemiskinan untk gugus non-sampel

$N_{d}^{-1}=$ Populasi rumah tangga kecamatan d yang nilainya didekatkan dengan populasi SP2010

$r_{d}$ adalah gugus rumah tangga non sampel yang nilai indikator kemiskinannya diestimasi melalui model M-kuantil. Untuk mempertimbangkan resiko bias pada estimasi di gugus $r_{d}$, model merujuk pada model estimasi distribusi Dunstan dan Chambers (1989)

$$
\begin{aligned}
& \hat{F}_{d}(t)=N_{d}^{-1}\left\{\sum_{j \epsilon s_{d}} I\left(\boldsymbol{y}_{j d} \leq t\right)+\right. \\
& \left.\sum_{k \epsilon r_{d}} n_{d}^{-1} \sum_{j \epsilon s_{d}} I\left\{\widehat{\boldsymbol{y}}_{k d}+\left(\boldsymbol{y}_{j d}-\widehat{\boldsymbol{y}}_{j d}\right) \leq t\right\}\right\}
\end{aligned}
$$

Persamaan di atas berbasis pada model linear $Q_{q_{j d}}(\mathbf{X} ; \psi)=\mathbf{X}_{j d}^{T} \beta_{\psi}\left(q_{j d}\right)$, regresi Mkuantil order ke- $q$ untuk distribusi bersyarat $\mathbf{y}_{j d}$ pada nilai $\mathbf{X}_{j d}$. Selanjutnya, estimasi indikator kemiskinan pada area- $d$ diperoleh melalui pendekatan rumus sebelumnya dan dikombinasikan dengan rumus umum kemiskinan, sehingga menjadi:

$$
\begin{gathered}
\hat{P}_{\alpha, d}(t)=N_{d}^{-1} \sum_{j \epsilon s_{d}}\left(\frac{t-\boldsymbol{y}_{j d}}{t}\right)^{\alpha} I\left(\boldsymbol{y}_{j d} \leq t\right) \\
+N_{d}^{-1} \sum_{k \epsilon r_{d}} n_{d}^{-1} \sum_{j \epsilon s_{d}}\left(\frac{t-\left(\hat{\boldsymbol{y}}_{k d}+\left(\boldsymbol{y}_{j d}-\widehat{\boldsymbol{y}}_{j d}\right)\right)}{t}\right)^{\alpha} I\left(\left(\widehat{\boldsymbol{y}}_{k d}+\right.\right. \\
\left.\left.\quad\left(\boldsymbol{y}_{j d}-\widehat{\boldsymbol{y}}_{j d}\right)\right) \leq t\right)
\end{gathered}
$$

$$
\begin{aligned}
& \operatorname{Untuk} \widehat{\boldsymbol{y}}_{j d}=\boldsymbol{X}_{j d}^{T} \widehat{\boldsymbol{\beta}}_{\psi}\left(\hat{\theta}_{d}\right) \text { dan } \widehat{\boldsymbol{y}}_{k d}= \\
& \boldsymbol{X}_{k d}^{T} \widehat{\boldsymbol{\beta}}_{\psi}\left(\hat{\theta}_{d}\right)
\end{aligned}
$$

Di mana: 
$\hat{\mathbf{y}}_{j d}$ adalah estimasi pengeluaran menghitung estimasi pengeluaran perkapita perkapita rumah tangga pada gugus sampel. di gugus non-sampel.

$\mathbf{X}_{j d}^{T} \quad$ adalah variabel penyerta yang $\quad \widehat{\boldsymbol{\beta}}_{\psi}\left(\hat{\theta}_{d}\right)$ adalah estimasi koefisien regresi diperoleh dari data SP2010 untuk kecamatan-d yang pada model M-kuantil menghitung estimasi pengeluaran perkapita diperoleh melalui Iterative Resample Least di gugus sampel.

$\hat{\mathbf{y}}_{k d}$ adalah estimasi pengeluaran Square (IRLS) dengan memasukkan fungsi pengaruh $(\psi)$ yang kontinyu. Fungsi perkapita rumah tangga pada gugus nonsampel.

$\mathbf{X}_{k d}^{T}$ adalah variabel penyerta yang diperoleh dari data SP2010 untuk pengaruh yang dipakai peneliti adalah tipe M-estimator yaitu Huber dan Hampel yang berguna untuk mengontrol nilai skala terhadap residual dan menjamin model bersifat kekar terhadap data pencilan.

Tabel 1.

Nilai tunning constant, scaled residual, dan pembobot pada fungsi pengaruh MKT, Huber, dan Hampel

\begin{tabular}{ccc}
\hline $\begin{array}{c}\text { Fungsi pengaruh } \\
\text { dan tunning constant }\end{array}$ & $\begin{array}{c}\text { Nilai scaled residual } \\
\text { MKT }\end{array}$ & $\begin{array}{c}\text { Rumus Pembobot } \\
\text { - }\end{array}$ \\
\hline Huber & jika $|u|<k$ & 1 \\
k $=1.345$ & jika $|u| \geq k$ & 1 \\
jika $|u|<a$ & $\frac{k}{|u|}$ \\
Hampel & jika $a \leq|u|<b$ & 1 \\
$\mathrm{~b}=4$ & jika $b \leq|u| \leq c$ & $\frac{a}{|u|}$ \\
$\mathrm{c}=8$ & lainnya & $\frac{c}{|u|}-1$ \\
& & $a-b$ \\
\hline
\end{tabular}
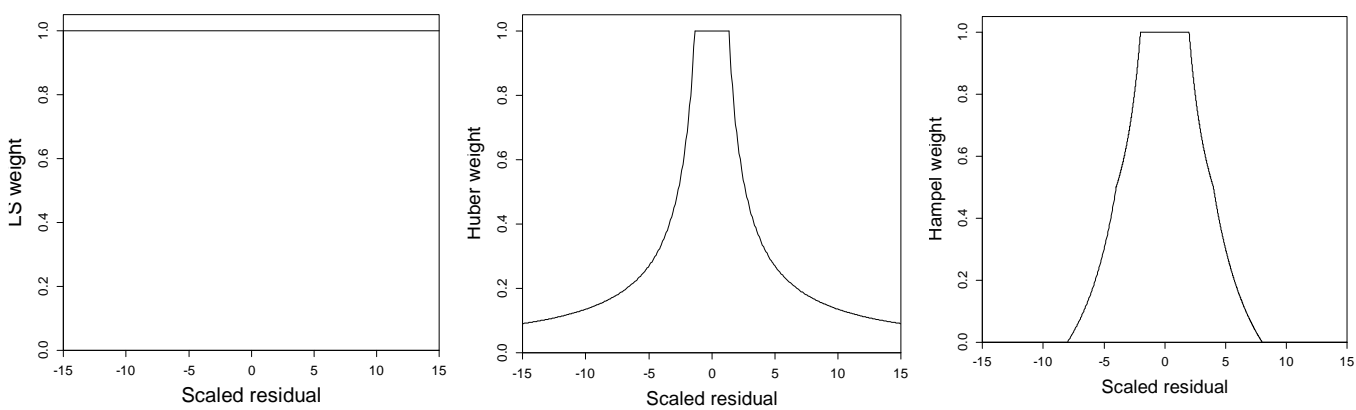

Gambar 1. Fungsi pembobot Huber, Hampel dan MKT 
Sumbu x pada Gambar 1 menunjukkan nilai scaled residual, sedangkan sumbu y menunjukkan nilai pembobot dari MKT, Huber, dan Hampel. Fungsi pembobot Hampel memberikan bobot nol terhadap nilai scaled residual tertentu, sedangkan MKT dan Huber tidak pernah memberikan bobot nol pada nilai scaled residual. MKT selalu meberikan bobot satu untuk semua nilai scaled residual. Gambar 1 menunjukkan bahwa fungsi pembobot $\mathrm{M}$ estimator memberikan nilai bobot yang semakin kecil pada bagian ekor sebaran. Hal ini berbeda dengan MKT yang selalu memberi nilai bobot sebesar satu untuk semua amatannya. Artinya, residual yang bernilai besar memiliki pengaruh yang lebih kecil terhadap pendugaan kekar dibandingkan jika memakai MKT.

\section{Sumber Data}

Data yang digunakan dalam penelitian ini merupakan data sekunder yang berasal dari Susenas Maret 2015, Suseda September 2015, dan Sensus Penduduk 2010 (SP2010) di Kabupaten Musi Rawas Provinsi Sumatera Selatan. Suseda digunakan untuk menambah jumlah sampel dan sekaligus membentuk model M-kuantil, sedangkan SP2010 digunakan sebagai penyedia variabel penyerta yang digunakan untuk mengestimasi nilai pengeluaran perkapita populasi sekaligus mengestimasi indikator kemiskinan.

Tabel 2.

Rincian sampel rumah tangga masing-masing kecamatan

\begin{tabular}{lccc}
\hline \multirow{2}{*}{$\begin{array}{c}\text { Nama } \\
\text { Kecamatan }\end{array}$} & Susenas & Suseda & Susenas+Suseda \\
\cline { 2 - 4 } & $\begin{array}{c}\text { Tanpa } \\
\text { Oversampling }\end{array}$ & & Oversampling \\
\hline STL Ulu & 30 & 90 & 120 \\
Selangit & 20 & 90 & 110 \\
Sumber Harta & 30 & 90 & 120 \\
Tugumulyo & 88 & 80 & 168 \\
Purwodadi & 30 & 89 & 119 \\
Muara Beliti & 20 & 90 & 110 \\
TP Kepungut & 10 & 90 & 100 \\
Jayaloka & 20 & 90 & 110 \\
Suka Karya & 30 & 90 & 120 \\
Muara Kelingi & 30 & 80 & 110 \\
BTS Ulu & 36 & 80 & 116 \\
Tuah Negeri & 30 & 80 & 110 \\
Muara Lakitan & 63 & 80 & 143 \\
Megang Sakti & 67 & 80 & 147 \\
\hline Jumlah & 504 & 1199 & 1703 \\
\hline
\end{tabular}


Penelitian ini menggunakan tiga variabel penyerta yang diperoleh menggunakan metode stepwise dan mempertimbangkan ketersediaan dan kesamaannya dengan variabel yang ada di SP2010, Susenas dan Suseda. Ketiga variabel terpilih tersebut yaitu jumlah anggota rumah tangga $\left(\mathrm{X}_{1}\right)$, lapangan usaha/pekerjaan $\mathrm{KRT}\left(\mathrm{X}_{2}\right)$, dan status/kedudukan KRT dalam usaha/pekerjaan $\left(\mathrm{X}_{3}\right)$. Variabel respon yang diamati pada penelitian ini adalah pengeluaran perkapita rumah tangga per bulan.

Tabel 3.

Daftar variabel yang digunakan beserta penjelasannya

\begin{tabular}{|c|c|c|c|c|}
\hline No & Nama Variabel & Kode & Satuan/Rincian & Penjelasan \\
\hline 1. & $\begin{array}{l}\text { Pengeluaran per } \\
\text { kapita rumah } \\
\text { tangga per bulan }\end{array}$ & Y & Rupiah & Susenas 2015 KP R25 \\
\hline 2. & $\begin{array}{l}\text { Jumlah anggota } \\
\text { rumah tangga }\end{array}$ & $\mathrm{X}_{1}$ & Orang & $\begin{array}{l}\text { Susenas } 2015 \text { Kor Blok } \\
\text { II R1, SP } 2010 \text { Blok I }\end{array}$ \\
\hline 3. & $\begin{array}{l}\text { Lapangan } \\
\text { usaha/pekerjaan } \\
\text { kepala rumah } \\
\text { tangga }\end{array}$ & $\mathrm{X}_{2}$ & $\begin{array}{l}1=\text { pertanian } \\
0=\text { non pertanian }\end{array}$ & $\begin{array}{l}\text { Susenas } 2015 \text { Kor R30, } \\
\text { SP } 2010 \text { R217 }\end{array}$ \\
\hline 4. & $\begin{array}{l}\text { Status dalam } \\
\text { pekerjaan }\end{array}$ & $\mathrm{X}_{3}$ & $\begin{array}{l}1=\text { berusaha sendiri/ } \\
\text { dibantu buruh } \\
0=\text { selain berusaha } \\
\text { sendiri/dibantu } \\
\text { buruh }\end{array}$ & $\begin{array}{c}\text { Susenas } 2015 \text { Kor R31, } \\
\text { SP } 2010 \text { R218 }\end{array}$ \\
\hline
\end{tabular}

\section{Tahapan Analisis}

Indikator kemiskinan dengan estimasi langsung mengikuti rumus FGT (1984):

$$
\hat{P}_{\alpha, d}^{D i r}=\frac{1}{n_{d}} \sum_{j=1}^{n_{d}}\left(\frac{t-y_{j d}}{t}\right)^{\alpha} I\left(\boldsymbol{y}_{j d} \leq t\right)(6)
$$

Sedangkan RMSE ( $\mathrm{P}_{\alpha, \mathrm{d}}^{\text {Dir }}$ ) pada estimasi langsung dihitung dengan menggunakan metode bootstrap dengan resampling sebanyak 100 kali $(B=100)$. Metode bootstrap menghasilkan $\widehat{\mathrm{P}}_{\alpha, \mathrm{d}}^{* \mathrm{~B}}$ untuk menghitung RMSE pada estimasi langsung sesuai rumus:

$$
\widehat{\operatorname{RMSE}}\left(P_{\alpha, d}^{D i r}\right)=\sqrt{B^{-1} \sum_{b=1}^{B}\left(\hat{P}_{\alpha, d}^{* B}-\hat{P}_{\alpha, d}^{D i r}\right)^{2}}
$$

Untuk estimasi model M-kuantil, diawali dengan menghitung koefisien regresi per kecamatan. Gunakan interpolasi untuk mendapatkan $q_{j d}$ sebagai koefisien unit Mkuantil untuk pasangan $\left(\mathbf{y}_{j d}, \mathbf{X}_{j d}\right)$ dari sampel yang memenuhi persamaan $\widehat{\boldsymbol{y}}_{j d}=$ $\mathbf{X}_{j d}^{T} \widehat{\boldsymbol{\beta}}_{\psi}\left(q_{j d}\right)$ di mana $\mathbf{y}_{j d}, \mathbf{X}_{j d} \in s_{d}$. Kemudian, hitung koefisien M-kuantil area sesuai rumus: 


$$
\widehat{\theta}_{d}=n_{d}^{-1} \sum_{j \in s_{d}} q_{j d}(8)
$$

Hitung estimasi $\widehat{\boldsymbol{\beta}}_{\psi}$ untuk koefisien Mkuantil kecamatan $\left(\hat{\theta}_{d}\right)$ pada persamaan $\hat{\mathbf{y}}_{j d}=\mathbf{X}_{j d}^{\mathrm{T}} \widehat{\boldsymbol{\beta}}_{\psi}\left(\hat{\theta}_{d}\right) \quad$ melalui Iterative Resampling Least Square (IRLS) dengan mengikuti tahapan berikut:

1. Dimulai iterasi ke-0, hitung estimasi awal $\widehat{\boldsymbol{\beta}}^{(0)}$ (koefisien regresi ke-0) mengunakan MKT.

2. Dengan memanfaatkan $\widehat{\boldsymbol{\beta}}^{(0)}$, dihasilkan residual $\mathbf{e}_{\mathrm{jd}}{ }^{(0)}$ dan nilai skala awal s${ }^{(0)}$. Penelitian ini menggunakan Median Absolute Deviation (MAD) untuk menghitung nilai skala (s).

3. Pilih fungsi pembobot $w(u)$ dan gunakan terhadap scaled residual $\mathbf{u}=$ $\frac{\mathbf{e}_{\mathrm{jd}}(0)}{\mathrm{s}^{(0)}}$ untuk mendapatkan bobot $\mathbf{w}_{\mathrm{jd}}{ }^{(0)}$ awal. Rumus umum $\mathrm{w}_{\mathrm{jd}}$ adalah $\mathrm{w}_{\mathrm{jd}}=$ $\left(1-\hat{\theta}_{\mathrm{d}}\right) \mathrm{w}(\mathrm{u})$ untuk $\mathbf{e}_{\mathrm{jd}} \leq 0$ dan $\mathbf{w}_{j d}=$ $\hat{\theta}_{d} w(u)$ untuk $\mathbf{e}_{j d}>0$. Bobot awal $\mathbf{w}_{j d}{ }^{(0)}$ menghasilkan matriks diagonal $\mathbf{W}^{(0)}$.

4. Lakukan iterasi ke-1 menggunakan $\mathbf{W}^{(0)}$ untuk mendapatkan estimasi baru $\widehat{\boldsymbol{\beta}}^{(1)}$ melalui rumus

$\widehat{\boldsymbol{\beta}}^{(1)}=$ $\left(\mathbf{X}^{T} \mathbf{W}^{(\mathbf{0})} \boldsymbol{X}\right)^{-1} \mathbf{X}^{T} \mathbf{W}^{(\mathbf{0})} \boldsymbol{y} . \quad$ Selanjutnya, dari estimasi $\widehat{\boldsymbol{\beta}}^{(1)}$, kita dapatkan residual baru $\mathbf{e}_{j d}{ }^{(1)}$. Dari residual baru, kita dapatkan $\mathbf{s}^{(1)}$ dan dengan fungsi pembobot, didapatkan bobot $w(u)$. Sampai pada tahap ini, didapatkan matriks diagonal $\mathbf{W}^{(\mathbf{1})}$.

5. Lakukan iterasi ke-2. Dengan menggunakan matris $\mathbf{W}^{(1)}$ didapatkan estimasi $\widehat{\boldsymbol{\beta}}^{(2)}, \mathbf{e}_{j d}{ }^{(2)}$, dan $\mathbf{s}^{(2)}$ yang baru. Tahap ini menghasilkan matriks diagonal $\mathbf{W}^{(2)}$.

6. Iterasi IRLS menggunakan rumus umum:

$$
\widehat{\boldsymbol{\beta}}^{(i t e r)}=\left(\boldsymbol{X}^{T} \boldsymbol{W}^{(i t e r-1)} \boldsymbol{X}\right)^{-1} \boldsymbol{X}^{T} \boldsymbol{W}^{(i t e r-1)} \boldsymbol{y}(9)
$$

Iterasi akan berhenti saat status konvergen tercapai. Konvergen adalah keadaan ketika perubahan residual lebih kecil dari nilai $\varepsilon$ dan didapatkan estimasi $\widehat{\boldsymbol{\beta}}_{\psi}$ akhir sebagai koefisien regresi Mkuantil. Konvergen dinyatakan dengan rumus:

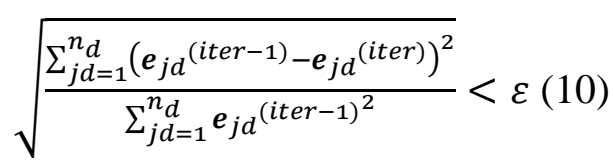

Di mana $\varepsilon$ adalah nilai kecil positif sebesar 0,0001.

Setelah memperoleh $\widehat{\boldsymbol{\beta}}_{\psi}$, hitung residual $\mathbf{e}_{\mathrm{jd}}=\mathbf{y}_{\mathrm{jd}}-\hat{\mathbf{y}}_{\mathrm{jd}}$ dan buat model $\hat{\mathbf{y}}_{\mathrm{kd}}=$ $\mathbf{X}_{\mathrm{kd}}^{\mathrm{T}} \widehat{\boldsymbol{\beta}}_{\psi}\left(\widehat{\theta}_{\mathrm{d}}\right)+\mathbf{e}_{\mathrm{jd}}^{*} \quad$ dimana $\quad \mathbf{e}_{\mathrm{jd}}^{*} \quad$ adalah sampel acak dengan pengembalian berukura $N_{\mathrm{d}}$ pada residual $\mathbf{e}_{\mathrm{jd}}$, sedangkan $\mathbf{X}_{\mathrm{kd}}$ adalah matriks variabel penyerta dari SP2010. Gunakan 50 iterasi simulasi monte carlo untuk menghitung estimasi $P_{0}$ dan $P_{2}$ berdasarkan pada rumus kemiskinan FGT:

$$
\hat{P}_{\alpha, d}^{L}=\frac{1}{N_{d}} \sum_{i=1}^{N_{d}}\left(\frac{t-\widehat{\boldsymbol{y}}_{k d}}{t}\right)^{\alpha} I\left(\widehat{\boldsymbol{y}}_{k d} \leq t\right)
$$

Hitung estimasi $P_{0}$ dan $P_{1}$ akhir dari rata-rata simulasi sebelumnya, yaitu:

$$
\hat{P}_{\alpha, d}=\frac{1}{L} \sum_{l=1}^{L} \hat{P}_{\alpha, d}^{* L}
$$

RMSE dihitung dengan mengadopsi rumus yang diusulkan Marchetti. Dimulai dengan membangkitkan bootstrap populasi $\mathrm{U}^{* \mathrm{~b}}$, di mana tiap $\mathrm{U}^{* \mathrm{~b}}$ dihitung estimasi $\widehat{\mathrm{P}}_{\alpha, \mathrm{d}}^{* \mathrm{~b}}$. Kemudian tiap $\mathrm{U}^{* \mathrm{~b}}$ diambil 100 kali bootstrap sampel $U^{* r}$ tanpa pengembalian sebanyak jumlah sampel area kecil $n_{d}^{*}=n_{d}$ untuk menghitung estimasi $\widehat{\mathrm{P}}_{\alpha, \mathrm{d}}^{* \text { br }}$. Sedangkan $\overline{\hat{P}}_{\alpha, d}^{* b r}$ adalah rata-rata $\hat{P}_{\alpha, d}^{* b r}$ sesuai persamaan berikut: 


$$
\widehat{\hat{P}}_{\alpha, d}^{* b r}=R^{-1} \sum_{r=1}^{R} \hat{P}_{\alpha, d}^{* b r}
$$

$$
R \widehat{R M S} E\left(\widehat{P}_{\alpha, d}\right)=\frac{\widehat{R M S E}\left(\hat{P}_{\alpha, d}\right)}{\hat{P}_{\alpha, d}} x 100 \%
$$

Estimasi bias dan varian sesuai rumus:

$$
\begin{gathered}
\hat{B}\left(\hat{P}_{\alpha, d}\right)=B^{-1} R^{-1} \sum_{b=1}^{B} \sum_{r=1}^{R}\left(\hat{P}_{\alpha, d}^{* b r}-\hat{P}_{\alpha, d}^{* b}\right) \\
\widehat{V}\left(\hat{P}_{\alpha, d}\right)=B^{-1} R^{-1} \sum_{b=1}^{B} \sum_{r=1}^{R}\left(\hat{P}_{\alpha, d}^{* b r}-\bar{P}_{\alpha, d}^{* b r}\right)^{2}(15)
\end{gathered}
$$

\section{HASIL DAN PEMBAHASAN}

Tabel 4 menunjukkan statistik deskriptif variabel pengeluaran perkapita rumah tangga. Rata-rata dan median dari survei

Sehingga rumus RMSE menjadi

$$
\widehat{\operatorname{RMSE}}\left(\widehat{P}_{\alpha, d}\right)=\sqrt{\widehat{B}\left(\hat{P}_{\alpha, d}\right)^{2}+\widehat{V}\left(\hat{P}_{\alpha, d}\right)}
$$
yang sampelnya ditambah (oversampling) berbeda tipis dengan survei yang sampelnya tetap. Simpangan baku pada oversampling lebih rendah dari sampel awal.

Bandingkan akurasi antara kedua teknik estimasi dengan memakai rumus RRMSE:

\section{Tabel 4.}

Pengeluaran Perkapita Rumah Tangga (rupiah)

\begin{tabular}{llllll}
\hline Data & Mean & Median & Std. Dev & Min & Max \\
\hline $\begin{array}{l}\text { Tanpa Penambahan } \\
\text { Sampel }\end{array}$ & 647751 & 547516 & 407918 & 191097 & 3507652 \\
$\begin{array}{l}\text { Dengan Penambahan } \\
\text { Sampel }\end{array}$ & 640368 & 573953 & 313455 & 169313 & 3507652 \\
\hline
\end{tabular}

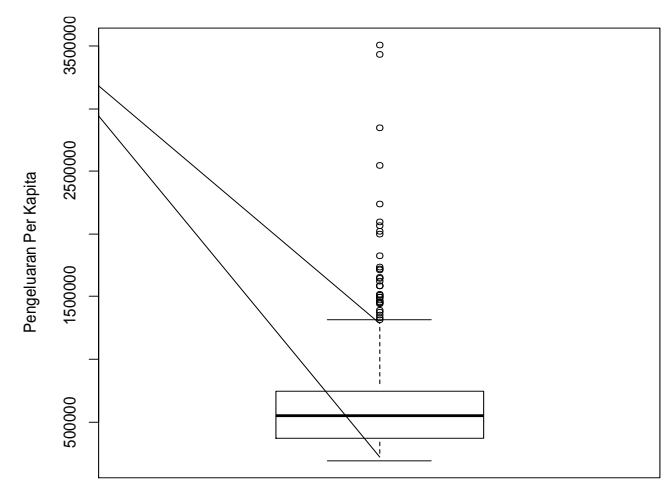

Kabupaten

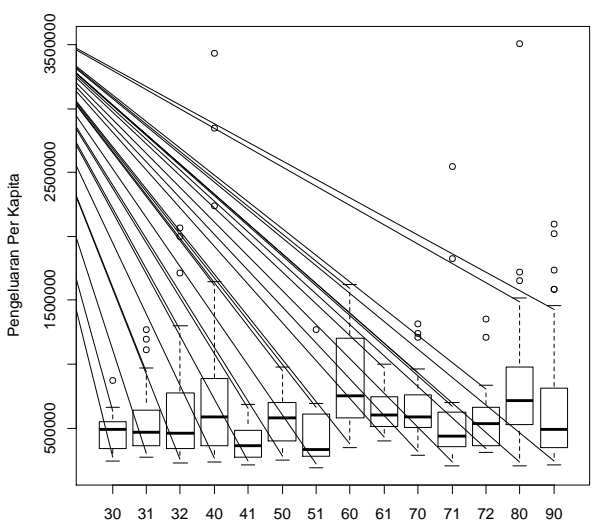

Kecamatan

Gambar 2 Boxplot pengeluaran perkapita rumah tangga kabupaten dan kecamatan di Kabupaten Musi Rawas (sampel kecil/awal) 


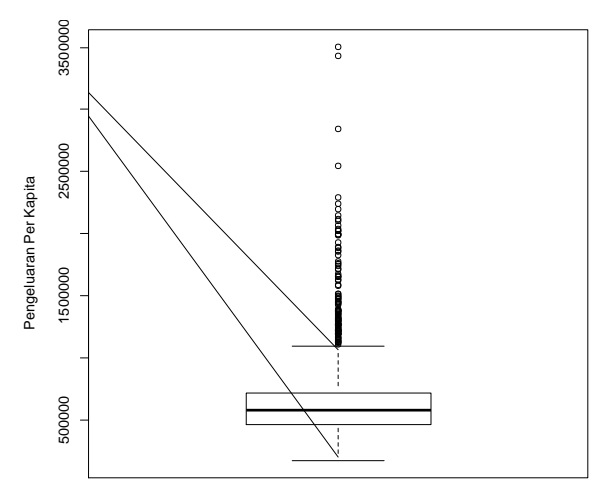

Kabupaten

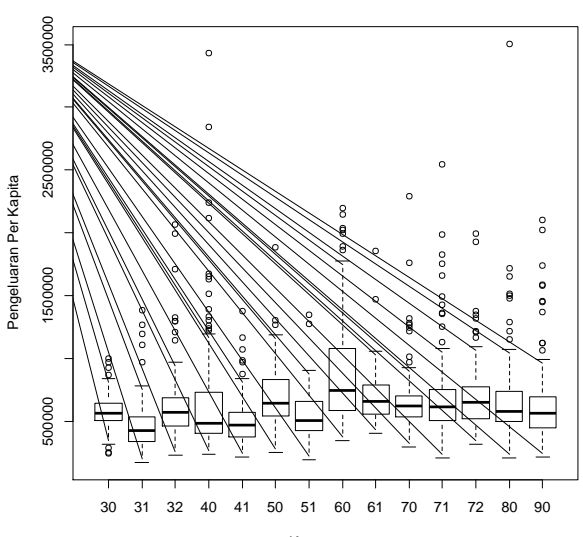

Kecamatan

Gambar 3. Boxplot pengeluaran perkapita rumah tangga kabupaten dan kecamatan di Kabupaten Musi Rawas (oversampling)

Gambar 2 dan 3 memperlihatkan pola sebaran pengeluaran perkapita rumah tangga per bulan dalam satu kabupaten maupun setiap kecamatan. Gambar memperlihatkan bahwa data pengeluaran perkapita rumah tangga per bulan dalam satu kabupaten maupun setiap kecamatan tidak simetris. Pola yang terbentuk menjulur kekanan (positive skewness). Hal ini diperkuat oleh adanya pencilan dibagian atas boxplot dan disertai whisker bagian atas lebih panjang. Adanya pencilan ini, apabila kita menggunakan metode kuadrat terkecil akan menghasilkan estimasi yang kurang baik. Oleh karena itu penggunaan metode estimasi yang bersifat kekar diperlukan sebagai metode alternatif yang sama baiknya dengan metode kuadrat terkecil tetapi tidak terlalu dipengaruhi oleh pencilan atau hal lain dalam asumsi model.

Tabel 5.

Nilai estimasi koefisien M-kuantil area $\hat{\theta}_{d}$

\begin{tabular}{llc}
\hline \multicolumn{1}{c}{ Kecamatan } & Huber & Hampel \\
\hline STL Ulu & 0.23 & 0.21 \\
Selangit & 0.38 & 0.36 \\
Sumber Harta & 0.42 & 0.41 \\
Tugumulyo & 0.48 & 0.47 \\
Purwodadi & 0.18 & 0.17 \\
Muara Beliti & 0.35 & 0.33 \\
TP Kepungut & 0.38 & 0.37 \\
Jayaloka & 0.70 & 0.69 \\
Suka Karya & 0.56 & 0.54 \\
Muara Kelingi & 0.55 & 0.53 \\
BTS Ulu & 0.32 & 0.30 \\
Tuah Negeri & 0.44 & 0.42 \\
Muara Lakitan & 0.70 & 0.69 \\
Megang Sakti & 0.38 & 0.37 \\
\hline
\end{tabular}


Tabel 5 menunjukkan nilai estimasi koefisien M-kuantil untuk kecamatan yang dihasilkan dari gugus sampel $\left(\mathbf{y}_{j d}, \mathbf{X}_{j d} \in s_{d}\right)$. Nilai tersebut merupakan rata-rata koefisien M-kuantil dari unit contoh. Nilai $\hat{\theta}_{d}$ menggambarkan posisi rataan kuantil pengeluaran per kapita berdasarkan data sampel setiap kecamatan. Setelah koefisien M-kuantil kecamatan $\left(\hat{\theta}_{d}\right)$ diperoleh, langkah selanjutnya adalah mencari estimasi $\beta_{\psi}$ bersyarat pada nilai koefisien M-kuantil kecamatan $\left(\hat{\theta}_{d}\right)$ menggunakan persamaan $\widehat{\boldsymbol{y}}_{j d}=\mathbf{X}_{j d}^{T} \widehat{\boldsymbol{\beta}}_{\psi}\left(\hat{\theta}_{d}\right)$ dimana $\mathbf{y}_{j d}$, $\mathbf{X}_{j d} \in s_{d}$.

Tabel 6 dan 7 menampilkan estimasi $\boldsymbol{\beta}_{\psi}$ pada nilai koefisien M-kuantil kecamatan $\left(\hat{\theta}_{d}\right)$. Interpretasi hasil tersebut adalah tiap kecamatan memiliki model estimasi regresi linier M-kuantil pada nilai kuantil $\hat{\theta}_{d}$ tertentu. Semakin tinggi nilai estimasi koefisien M-kuantil area $\hat{\theta}_{d}$, hasil nilai estimasi $\boldsymbol{\beta}_{\psi}$ pada nilai koefisien M-kuantil $\hat{\theta}_{d}$ makin besar. Nilai estimasi pada variabel penyerta pertama dan kedua yang bernilai negatif menunjukkan keduanya memiliki hubungan berbanding terbalik dengan variabel respon. Nilai estimasi pada variabel penyerta ketiga yang bernilai positif menunjukkan hubungan searah dengan peubah respon.

Tabel 6 .

Estimasi $\boldsymbol{\beta}_{\psi}$ pada koefisien M-kuantil $\hat{\theta}_{d}$ dengan fungsi pembobot Huber

\begin{tabular}{lrrrr}
\hline \multicolumn{1}{c}{ Kec } & \multicolumn{1}{c}{$\hat{\beta}_{0 \psi}\left(\hat{\theta}_{d}\right)$} & $\hat{\beta}_{1 \psi}\left(\hat{\theta}_{d}\right)$ & $\hat{\beta}_{2 \psi}\left(\hat{\theta}_{d}\right)$ & $\hat{\beta}_{3 \psi}\left(\hat{\theta}_{d}\right)$ \\
\hline STL Ulu & 766992.4 & -69194.7 & -77671.1 & 36698.0 \\
Selangit & 902718.8 & -77876.0 & -127736.6 & 45966.7 \\
Sumber Harta & 949235.7 & -80600.1 & -147522.4 & 49410.4 \\
Tugumulyo & 1009244.0 & -84017.6 & -172725.6 & 54251.8 \\
Purwodadi & 721620.6 & -66436.9 & -63296.8 & 33547.4 \\
Muara Beliti & 875280.2 & -76131.4 & -117157.2 & 44155.7 \\
TP Kepungut & 904642.1 & -77994.0 & -128524.6 & 46089.9 \\
Jayaloka & 1318612.4 & -97977.9 & -336633.6 & 91924.3 \\
Suka Karya & 1100052.4 & -88402.0 & -217727.8 & 63148.5 \\
Muara Kelingi & 1087667.8 & -87802.0 & -211560.2 & 61699.0 \\
BTS Ulu & 854139.1 & -74803.6 & -109348.1 & 42862.3 \\
Tuah Negeri & 965230.9 & -81518.3 & -154313.3 & 50784.2 \\
Muara Lakitan & 1315490.3 & -97852.4 & -334928.9 & 91472.8 \\
Megang Sakti & 909109.4 & -78267.4 & -130397.8 & 46383.1 \\
\hline
\end{tabular}


Tabel 7.

Estimasi $\boldsymbol{\beta}_{\psi}$ pada koefisien M-kuantil $\hat{\theta}_{d}$ dengan fungsi pembobot Hampel

\begin{tabular}{lrrrr}
\hline \multicolumn{1}{c}{ Kec } & \multicolumn{1}{c}{$\hat{\beta}_{0 \psi}\left(\hat{\theta}_{d}\right)$} & $\hat{\beta}_{1 \psi}\left(\hat{\theta}_{d}\right)$ & $\hat{\beta}_{2 \psi}\left(\hat{\theta}_{d}\right)$ & $\hat{\beta}_{3 \psi}\left(\hat{\theta}_{d}\right)$ \\
\hline STL Ulu & 754439.9 & -68663.4 & -63370.5 & 37139.1 \\
Selangit & 901399.0 & -77593.8 & -120993.4 & 48083.9 \\
Sumber Harta & 952677.5 & -80722.1 & -142270.8 & 52142.1 \\
Tugumulyo & 1003778.3 & -83604.6 & -161301.0 & 56660.7 \\
Purwodadi & 711816.0 & -65965.0 & -49961.5 & 34139.4 \\
Muara Beliti & 867871.7 & -75494.3 & -107685.8 & 45507.4 \\
TP Kepungut & 915395.3 & -78439.8 & -126587.0 & 49126.7 \\
Jayaloka & 1309172.6 & -99245.3 & -312559.4 & 89596.2 \\
Suka Karya & 1074945.8 & -87789.2 & -191578.8 & 63456.4 \\
Muara Kelingi & 1063944.0 & -87157.2 & -186649.5 & 62316.1 \\
BTS Ulu & 844751.4 & -74076.8 & -98428.7 & 43642.1 \\
Tuah Negeri & 961489.4 & -81263.5 & -145799.5 & 52924.6 \\
Muara Lakitan & 1296307.3 & -98722.5 & -305126.7 & 87961.5 \\
Megang Sakti & 909048.8 & -78047.0 & -123893.4 & 48630.5 \\
\hline
\end{tabular}

Tabel 8 menampilkan hasil estimasi oversampling dan estimasi model M-kuantil $P_{0}$ menggunakan estimasi langsung dengan di seluruh kecamatan.

Tabel 8.

Estimasi $P_{0}$ tingkat kecamatan (dalam persen)

\begin{tabular}{|c|c|c|c|}
\hline \multirow{3}{*}{ Nama Kecamatan } & \multirow{2}{*}{\multicolumn{2}{|c|}{$\begin{array}{c}\text { Estimasi tidak } \\
\text { langsung } \\
\text { dengan M-kuantil }\end{array}$}} & \multirow{3}{*}{$\begin{array}{c}\text { Estimasi langsung } \\
\text { oversampling }\end{array}$} \\
\hline & & & \\
\hline & Huber & Hampel & \\
\hline STL Ulu & 29.18 & 29.93 & 5 \\
\hline Selangit & 24.47 & 24.08 & 27.27 \\
\hline Sumber Harta & 14.61 & 14.05 & 7.5 \\
\hline Tugumulyo & 9.16 & 9.09 & 11.9 \\
\hline Purwodadi & 27.33 & 27.81 & 15.97 \\
\hline Muara Beliti & 20.28 & 20.4 & 1.82 \\
\hline TP Kepungut & 22.86 & 21.67 & 12 \\
\hline Jayaloka & 6.6 & 6.37 & 0 \\
\hline Suka Karya & 10.43 & 10.58 & 0 \\
\hline Muara Kelingi & 11.77 & 12.08 & 1.82 \\
\hline BTS Ulu & 19.29 & 19.45 & 5.17 \\
\hline Tuah Negeri & 15.48 & 15.54 & 3.64 \\
\hline Muara Lakitan & 7.47 & 7.57 & 2.8 \\
\hline Megang Sakti & 15.7 & 15.37 & 10.88 \\
\hline
\end{tabular}




\begin{tabular}{lccc}
\hline \multirow{2}{*}{ Nama Kecamatan } & \multicolumn{2}{c}{$\begin{array}{c}\text { Estimasi tidak } \\
\text { langsung } \\
\text { dengan M-kuantil }\end{array}$} & $\begin{array}{c}\text { Estimasi langsung } \\
\text { oversampling }\end{array}$ \\
\cline { 2 - 3 } & Huber & Hampel & \\
\hline Rata-rata $^{\mathrm{a}}$ & 18.13 & 18.09 & 8.81 \\
Median $^{\mathrm{a}}$ & 17.5 & 17.5 & 6.34 \\
Level Kab & 16.08 & 15.95 & 7.63 \\
\hline
\end{tabular}

a Penghitungan rata-rata dan median tidak melibatkan Kecamatan Jayaloka dan Suka karya

Terlihat pada tabel, bahwa M-kuantil estimasi langsung dengan oversampling mampu melakukan estimasi angka menghasilkan persentase penduduk miskin kemiskinan $P_{0}$ yang bernilai lebih dari 0\% lebih rendah dibandingkan M-kuantil. pada kecamatan Jayaloka dan Suka Karya, Gambar 6 berikut menampilkan grafik yang sebelumnya estimasi langsung $P_{0}$ pada perbandingan estimasi langsung dengan dua kecamatan tersebut sebesar $0 \%$. Selain oversampling dan M-kuantil fungsi itu, terlihat hasil estimasi $P_{0}$ menggunakan pembobot Huber.

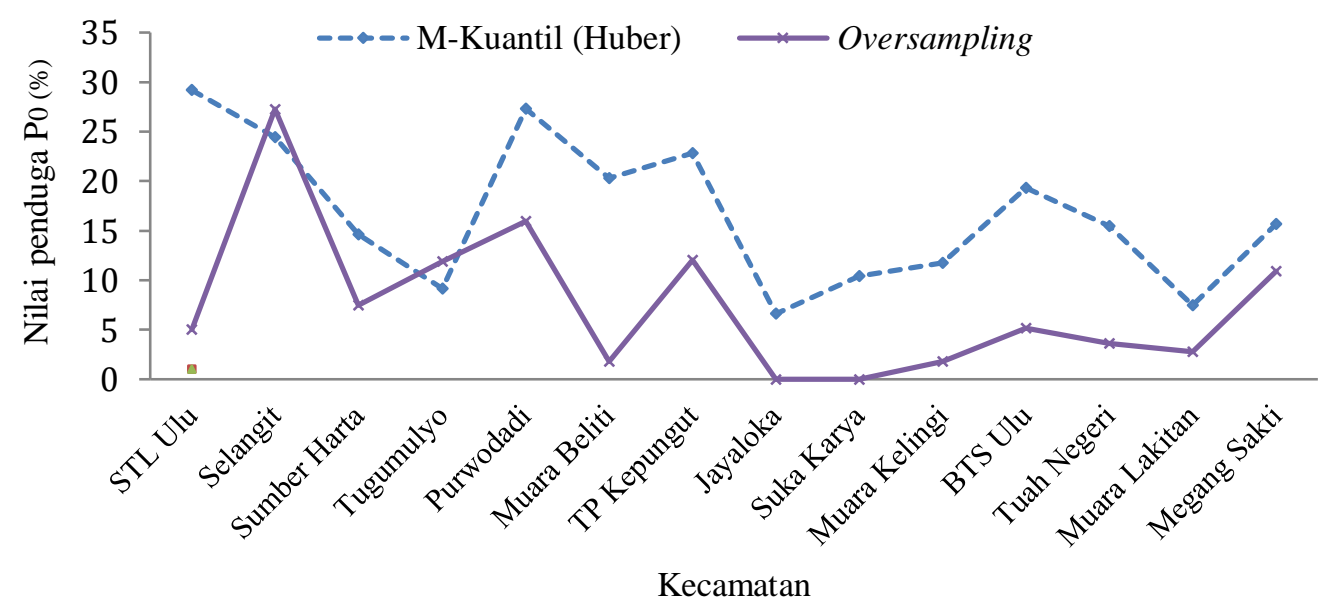

Gambar 4.

Perbandingan estimasi $P_{0}$ kecamatan

Tabel 9 menunjukkan RRMSE estimasi $P_{0}$ pada estimasi langsung oversampling dan M-Kuantil. Rata-rata RRMSE estimasi $P_{0}$ pada estimasi tidak langsung lebih kecil dari estimasi langsung, artinya M-kuantil lebih akurat dibandingkan dengan estimasi langsung dengan oversampling. Simpangan baku dan median RRMSE $P_{0}$ melalui $\mathrm{M}$ kuantil juga lebih kecil dibandingkan dengan estimasi langsung oversampling. 
Tabel 9.

RRMSE estimasi $P_{0}$ tingkat kecamatan (dalam persen)

\begin{tabular}{|c|c|c|c|}
\hline \multirow[t]{2}{*}{ Nama Kecamatan } & \multicolumn{2}{|c|}{$\begin{array}{c}\text { Estimasi tidak } \\
\text { langsung } \\
\text { dengan M-kuantil }\end{array}$} & \multirow[t]{2}{*}{$\begin{array}{c}\text { Estimasi langsung } \\
\text { oversampling }\end{array}$} \\
\hline & Huber & Hampel & \\
\hline STL Ulu & 35.23 & 34.78 & 39.92 \\
\hline Selangit & 18.84 & 21.6 & 15.56 \\
\hline Sumber Harta & 29.1 & 26.91 & 31.88 \\
\hline Tugumulyo & 21.07 & 23.98 & 20.77 \\
\hline Purwodadi & 48.66 & 48 & 21.1 \\
\hline Muara Beliti & 27.31 & 22.5 & 70.7 \\
\hline TP Kepungut & 30 & 32.13 & 27.29 \\
\hline Jayaloka & 73 & 57.94 & - \\
\hline Suka Karya & 50.24 & 38.38 & - \\
\hline Muara Kelingi & 39.26 & 32.61 & 70.05 \\
\hline BTS Ulu & 26.75 & 27.35 & 39.68 \\
\hline Tuah Negeri & 24.87 & 24.33 & 49.47 \\
\hline Muara Lakitan & 43.79 & 39.65 & 49.69 \\
\hline Megang Sakti & 18.41 & 20.3 & 23.38 \\
\hline Rata-rata $^{\mathrm{a}}$ & 30.27 & 29.51 & 38.29 \\
\hline Median $^{\mathrm{a}}$ & 28.21 & 27.13 & 35.78 \\
\hline Simp baku ${ }^{a}$ & 9.7 & 8.28 & 18.64 \\
\hline
\end{tabular}

${ }^{a}$ Penghitungan rata-rata, median, dan simpangan baku tidak melibatkan Kecamatan Jayaloka dan Suka karya

Tabel 10 menunjukkan bahwa $\mathrm{M}$ - kemiskinan $\left(P_{1}\right)$ yang tidak lagi bernilai 0\% Kuantil mampu mengungkap kedalaman untuk Kecamatan Jayaloka dan Suka Karya.

Tabel 10 .

Estimasi $P_{1}$ tingkat kecamatan (dalam persen)

\begin{tabular}{lrrr}
\hline \multirow{2}{*}{ Nama Kecamatan } & \multicolumn{2}{c}{$\begin{array}{c}\text { Estimasi tidak langsung } \\
\text { dengan M-kuantil }\end{array}$} & \multirow{2}{*}{$\begin{array}{c}\text { Estimasi langsung } \\
\text { oversampling }\end{array}$} \\
\cline { 2 - 3 } & Huber & Hampel & \\
\hline STL Ulu & 10.33 & 10.63 & 0.68 \\
Selangit & 9.37 & 9.2 & 3.82 \\
Sumber Harta & 4.35 & 4.15 & 1.38 \\
Tugumulyo & 2.73 & 2.7 & 1.77 \\
Purwodadi & 8.33 & 8.52 & 3.36 \\
Muara Beliti & 6.72 & 6.76 & 0.39 \\
TP Kepungut & 8.35 & 8.01 & 1.2 \\
Jayaloka & 2.19 & 2.17 & 0 \\
Suka Karya & 3.18 & 3.21 & 0 \\
Muara Kelingi & 4.03 & 4.1 & 0.19 \\
\hline
\end{tabular}




\begin{tabular}{|c|c|c|c|}
\hline \multirow[t]{2}{*}{ Nama Kecamatan } & \multicolumn{2}{|c|}{$\begin{array}{c}\text { Estimasi tidak langsung } \\
\text { dengan M-kuantil }\end{array}$} & \multirow{2}{*}{$\begin{array}{l}\text { Estimasi langsung } \\
\text { oversampling }\end{array}$} \\
\hline & Huber & Hampel & \\
\hline BTS Ulu & 6.12 & 6.22 & 0.73 \\
\hline Tuah Negeri & 4.96 & 4.89 & 0.16 \\
\hline Muara Lakitan & 2.58 & 2.6 & 0.7 \\
\hline Megang Sakti & 4.65 & 4.54 & 1.59 \\
\hline Rata-rata $^{\mathrm{a}}$ & 6.04 & 6.03 & 1.33 \\
\hline Median $^{\mathrm{a}}$ & 5.54 & 5.56 & 0.97 \\
\hline Level Kab & 5.3 & 5.2 & 1.16 \\
\hline
\end{tabular}

Tabel 11 menunjukkan RRMSE lebih akurat dibandingkan dengan estimasi estimasi $P_{1}$ pada estimasi langsung dan M- langsung oversampling. Dilihat dari nilai Kuantil. Rata-rata estimasi M-kuantil lebih median, estimasi M-kuantil juga lebih kecil dari estimasi langsung sehingga bisa unggul dibandingkan estimasi langsung. diambil kesimpulan bahwa M-kuantil masih

Tabel 11.

RRMSE estimasi $P_{1}$ tingkat kecamatan (dalam persen)

\begin{tabular}{lccc}
\hline \multicolumn{1}{c}{ Nama Kecamatan } & $\begin{array}{c}\text { Estimasi tidak langsung } \\
\text { dengan M-kuantil }\end{array}$ & $\begin{array}{c}\text { Estimasi } \\
\text { langsung } \\
\text { oversampling }\end{array}$ \\
\cline { 2 - 4 } & Huber & Hampel & \\
\hline STL Ulu & 40.85 & 41.32 & 52.21 \\
Selangit & 25.84 & 29.01 & 23.27 \\
Sumber Harta & 42.73 & 41.67 & 38.1 \\
Tugumulyo & 34.47 & 34.48 & 24.96 \\
Purwodadi & 69.5 & 60.42 & 22.99 \\
Muara Beliti & 36.16 & 28.56 & 73.14 \\
TP Kepungut & 45.52 & 43.56 & 45.19 \\
Jayaloka & 72.5 & 58.88 & - \\
Suka Karya & 72.24 & 56.75 & - \\
Muara Kelingi & 48.4 & 43.44 & 77.08 \\
BTS Ulu & 30.58 & 33.44 & 55.32 \\
Tuah Negeri & 38.33 & 38.86 & 67.56 \\
Muara Lakitan & 46.09 & 41.53 & 58.17 \\
Megang Sakti & 28.81 & 29.09 & 28.38 \\
\hline Rata-rata ${ }^{\text {a }}$ & 40.61 & 38.78 & 47.2 \\
Median & 39.59 & 40.09 & 48.7 \\
Simp baku & 11.58 & 8.92 & 19.74 \\
\hline Penghitungan rata-rata, median, dan simpangan baku tidak melibatkan \\
Kecamatan Jayaloka dan Suka karya & & \\
& & &
\end{tabular}




\begin{abstract}
Perbandingan Estimasi Langsung terkecil untuk $P_{0}$ adalah Hampel dengan Estimasi Tidak Langsung

Secara umum, model M-kuantil telah menunjukkan bahwa M-kuantil layak menghasilkan rata-rata RRMSE $P_{0}$ dan $P_{1}$ digunakan sebagai alternatif untuk lebih kecil dibandingkan dengan estimasi menggantikan penambahan sampel pada langsung oversampling. Fungsi pembobot Suseda sekaligus mampu meningkatkan yang menghasilkan RRMSE rata-rata akurasinya.
\end{abstract}

Tabel 12.

Rata-rata RRMSE estimasi indikator kemiskinan (\%)

\begin{tabular}{cccc}
\hline Teknik Estimasi & HCR & PG & PS \\
\hline $\begin{array}{l}\text { Estimasi langsung } \\
\text { Dengan Oversampling }\end{array}$ & 38.29 & 47.2 & 55.94 \\
Estimasi tidak langsung (M-kuantil) & & & \\
$\quad$ Huber & 30.27 & 40.61 & 48.99 \\
Hampel & 29.51 & 38.78 & 46.01 \\
\hline
\end{tabular}

\section{SIMPULAN}

Pada estimasi langsung, terdapat dua kecamatan yang estimasi indikator kemiskinannya sebesar $0 \%$. Hal ini menunjukkan bahwa penambahan sampel hanya meningkatkan akurasi. Sebaliknya, M-kuantil mampu menghitung estimasi indikator kemiskinan pada beberapa kecamatan yang indikator kemiskinannya 0\% jika menggunakan estimasi langsung. Berdasarkan penelitian ini, kami menyimpulkan bahwa M-kuantil mampu menggantikan survei tambahan dengan penambahan sampel. Penambahan sampel tidak perlu dilakukan lagi karena tidak efisien.

Berdasarkan rata-rata RRMSE, Mkuantil menghasilkan estimasi yang lebih akurat dibandingkan estimasi langsung oversampling. Kesimpulan lain dari penelitian ini menunjukkan bahwa fungsi pembobot Hampel lebih baik dari Huber karena memberikan rata-rata RRMSE yang lebih rendah.

\title{
DAFTAR PUSTAKA
}

Badan Pusat Statistik. (2016). Data dan Informasi Kemiskinan Kabupaten/ Kota (2015). Jakarta: Badan Pusat Statistik.

Breckling J, Chambers R. (1988). M-quantiles. Biometrika. 75(4).761-771.

Chambers R., Tzavidis N. (2006). M-Quantile Models for small area estimation. Biometrika. 93(2).255-268.

Draper NR, Smith H. (1998). Applied Regression Analysis Third Edition. New York (US): Wiley.

Dunstan R, Chambers R. (1989). Estimating Distribution Functions from Survey Data with Limited Benchmark Information. Austral. J. Statist. 31(1).1-11. 
Foster J., Greer J., Thorbecke E. (1984). A class of decomposable poverty measures. Econometrica, 52(3).761-766.

Girinoto. (2017). Kajian pendugaan area kecil untuk indikator kemiskinan melalui pendekatan regresi kekar M-kuantil (studi kasus: tingkat kecamatan pada Kabupaten Bogor) M.Si thesis. Institut Pertanian Bogor, Bogor.

Giusti C., Marchetti S., Pratesi M., Salvati N. (2012). Robust small area estimation and oversampling in the estimation of poverty indicators. Survey Research Methods. 6(3). 155-163.

Huber PJ, Ronchetti EM. (2009). Robust Statistics. New York (US): John Wiley \& Sons.

Kennickell A.B. (2007). The Role of Oversampling of the Wealthy in the Survey of Consumer Finances. ISI 56th conference.

Koenker R, Bassett G. (1978). Regression quantiles. Econometrica. 46(1).33-50.

Marchetti S., Tzavidis N., Pratesi M. (2012). Non-parametric bootstrap mean squared error estimation for M-quantile estimators of small area averages, quantiles and poverty indicators. Computational Statstics and Data Analysis, 56.2889-2902.

Molina I, Rao J.N.K. (2010). Small area estimation of poverty indicators. The Canadian Journal of Statistics. 38(3).369-385.

Montgomery, DC, Peck, EA, Vining GG. (2012). Introduction to Linear Regression Analysis Fifth Edition. New York (US): John Wiley \& Sons.

Rao J.N.K. (2003). Small Area Estimation. New York, US: John Wiley and Sons.

Tzavidis N., Marchetti S., Chambers R. (2010). Robust Estimation of Small Area Means and Quantiles. Australian and New Zealand Journal of Statistics. 52(2).167-186. 